\title{
SISTEM INFORMASI ORDER FULFILLMENT UNTUK USAHA KECIL MENENGAH
}

\section{Order Fulfillment Information System for Small Medium Business}

\author{
Johanes Fernandes Andry') dan Reinaldo ${ }^{2)}$ \\ 1) Sistem Informasi/Fakultas Teknologi dan Desain, Bunda Mulia University \\ 2) Sistem Informasi/Fakultas Teknologi dan Desain, Bunda Mulia University \\ Diterima 06 December 2017 / Disetujui 26 January 2018
}

\begin{abstract}
Companies will know the needs, ideals, advantages and lack of self. Especially if this is associated with order fulfillment management in a company, especially in SMB = small medium business. Development for order fulfillment and customer service capabilities, to get measurement right. Measurement provides the road map for helping SMB from as-is capabilities to desired to-be. Fulfillment Process is a key process in managing the chain. Supply is a customer order that puts the supply chain in motion, and filling it efficiently and effectively is the first step in providing customer service. In this case framework of thinking used Software Development Life Cycle (SDLC) is a process used by software industry to design, develop software. Based on the development of Order Fulfillment Information System, a source of information is needed to direct a better development process. Therefore, business processes as information related to development have been obtained from businesses that need such information systems. Proposed System Based on the business processes described earlier, the analysis of the Order Fulfillment information system creation is made using Unified Modeling Language (UML). Conclusion of Order fulfillment Information System for Small Medium Business are Fast data processing, the timeliness of the information received means that if the information received is too late Then this will reduce the value of the benefits of information itself, It has a high degree of information accuracy; accurate information is information that is full of certainty, Efficiency of human resources and Easy access to information.
\end{abstract}

Keywords: Small Medium Business, SDLC, UML, Order Fulfillment

\begin{abstract}
ABSTRAK
Perusahaan akan tahu kebutuhan, cita-cita, kelebihan dan kekurangan diri. Terutama jika hal ini dikaitkan dengan manajemen Order Fulfillment dalam suatu perusahaan, terutama di UKM = usaha kecil menengah. Pengembangan untuk Order Fulfillment dan kemampuan layanan pelanggan, untuk mendapatkan pengukuran yang tepat. Pengukuran menyediakan peta jalan untuk membantu UKM dari apa adanya kemampuan yang diinginkan. Proses Pemenuhan adalah proses kunci dalam mengelola rantai. Pasokan adalah pesanan pelanggan yang membuat rantai pasokan bergerak, dan mengisinya secara efisien dan efektif adalah langkah pertama dalam menyediakan layanan pelanggan. Dalam hal ini kerangka berfikir menggunakan Software Development Life Cycle (SDLC) adalah proses yang digunakan oleh industri perangkat lunak untuk merancang, mengembangkan perangkat lunak. Berdasarkan perkembangan Sistem Informasi Order Fulfillment, sumber informasi diperlukan untuk mengarahkan proses pengembangan yang lebih baik. Oleh karena itu, proses bisnis sebagai informasi yang terkait dengan pengembangan telah diperoleh dari bisnis yang membutuhkan sistem informasi tersebut. Usulan Sistem Berdasarkan proses bisnis yang dijelaskan sebelumnya, analisis pembuatan sistem informasi Order Fulfillment dibuat menggunakan Unified Modeling Language (UML). Kesimpulan Pemenuhan Ketertiban Sistem Informasi untuk Usaha Kecil Menengah adalah pengolahan data cepat, ketepatan waktu dari informasi yang diterima berarti bahwa jika informasi yang diterima terlambat. Maka ini akan mengurangi nilai manfaat dari informasi itu sendiri, Ini memiliki tingkat informasi yang tinggi. ketepatan; informasi yang akurat adalah informasi yang penuh dengan kepastian, Efisiensi sumber daya manusia dan Akses mudah ke informasi.
\end{abstract}


Kata Kunci: Usaha Kecil Menengah, SDLC, UML, Order Fulfillment

\section{INTRODUCTION}

One of the things that is interesting enough to be observed is the ability of entrepreneurs engaged in the sector of small and medium industries in the country to analyze the potential of themselves and the potential of the company owned. By recognizing themselves, individuals and companies will know the needs, ideals, advantages and lack of self. Especially if this is associated with order fulfillment management in a company (especially in $\mathrm{SMB}=$ small medium business $)$.

Order fulfillment is a key process in managing the supply chain management (Croxton, 2002). Order fulfillment is in the very general sense the complete process from point of sales inquiry to delivery of a product to the customer. Sometimes Order fulfillment is used to describe the narrower act of distribution or the logistics function, however, in the broader sense it refers to the way firms respond to customer orders (Isac, 2014 \& Andry, et all 2016). Development for order fulfillment and customer service capabilities, to get measurement right. Measurement provides the road map for helping you to go from your "as-is" capabilities to your desired "tobe" capabilities (Fawcett, 2014). So that the company is expected to be able to fulfill the order with a stand on the slogan delivery it to the right place, at the right time for the right price (Rahmanto, 2011 \& Murphy, 2004).

The Order Fulfillment as shown in Figure 1. Fulfillment Process is a key process in managing the chain. Supply is a customer order that puts the supply chain in motion, and filling it efficiently and effectively is the first step in providing customer service. However, the fulfillment process command involves much more than just filling orders. Designing networks and processes that enable companies to meet customer demands while minimizing total costs delivered. The Fulfillment Order process is explained in detail to show how it can be cross-functionally implemented within a company, and managed across the enterprise in the supply chain. The activities of each sub-process are examined; Interfaces with corporate functions, processes and enterprises are evaluated, a successful example of implementation is provided.

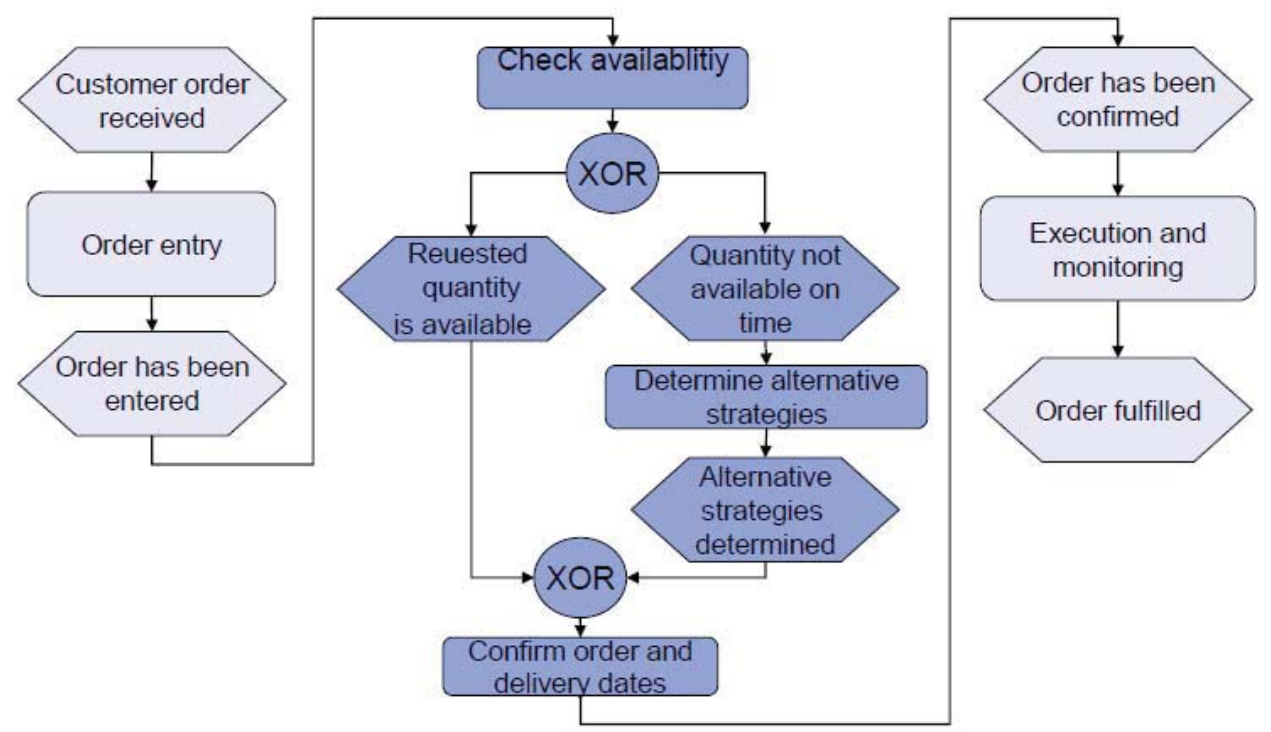

Figure 1. Fulfillment Process (Pibernik, 2006). 
Previous research conducted by Hartono et all, Analisis Manajemen Pemenuhan Pelanggan pada Industri Kecil Menengah Pembuatan Tas dan Bordir Menggunakan Pemodelan System Dynamics (Studi Kasus pada CV. Kurnia Jaya - Yogyakarta), has been produced conclusion As follows Factors that affect the policy in customer order fulfillment management CV. Kurnia Jaya is covered in key variables: order backlog, delivery delay, production rate, raw material inventory and labor.

\section{RESEARCH METHODS}

\section{Design Research with SDLC Waterfall}

In this case framework of thinking used Software Development Life Cycle (SDLC) is a process used by software industry to design, develop and test high quality software. The SDLC aims to produce high quality software that meets or exceeds customer expectations, reaches completion within times and cost estimates. The software development life cycle is a framework defining tasks performed at each step in the software development process. SDLC is a process followed for a software project, within a software organization. It consists of a detailed plan describing how to develop, maintain, replace and alter or enhance specific software. The Waterfall model was proposed by Winston W. Royce in 1970 to describe a possible software engineering practice (Bassil, 2012). The life cycle defines a methodology for improving the quality of software and the overall development process. Shown in Figure. 2 Procedure of Research.

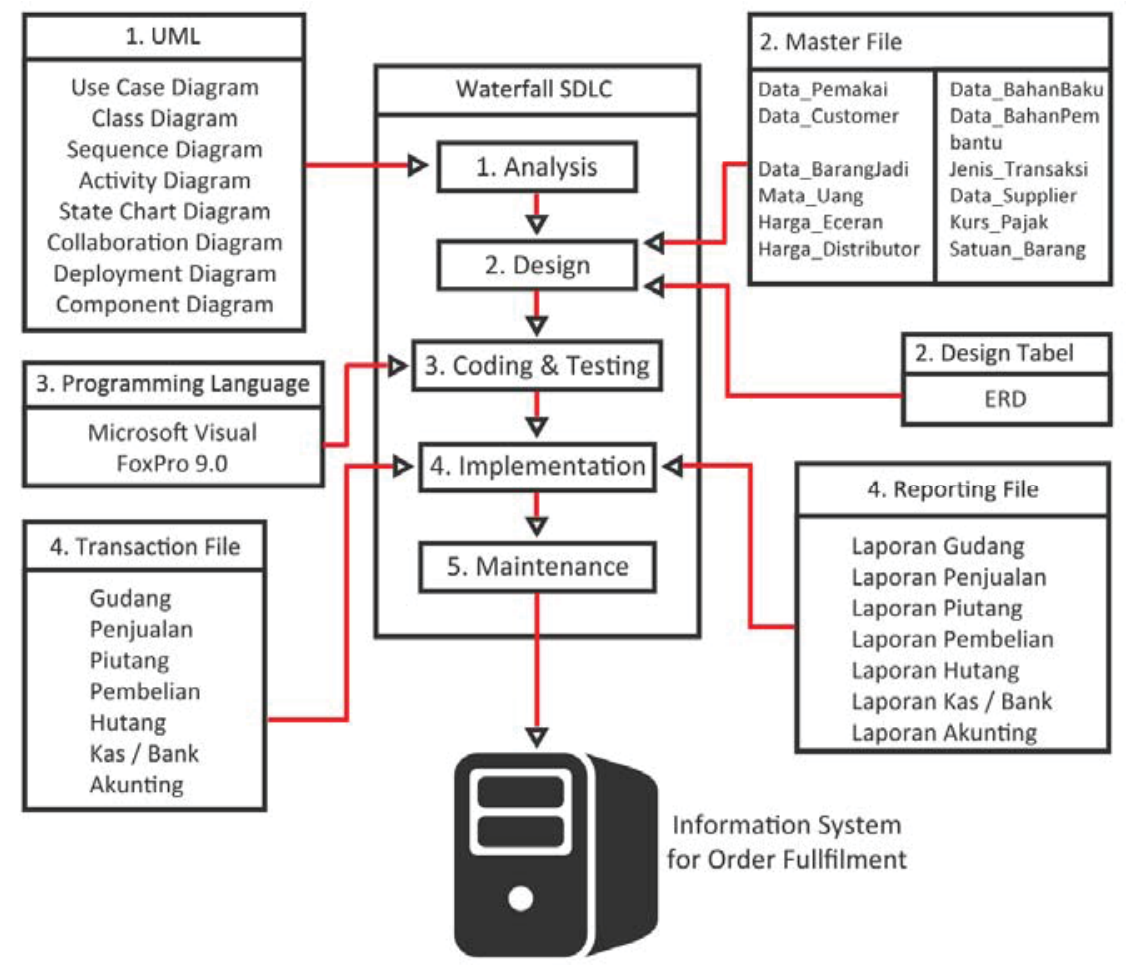

Figure. 2 Procedure of Research

Stages of system development used to perform activities in preparing a system that will be done in order to achieve the desired results. Therefore this stage will be very useful for those who are doing system development. This modeling begins by searching for the needs of the whole system to be applied into the form of software. This is very important, considering the software must be able to interact with other elements such as hardware, databases, etc.

Analysis is a business domain study problem to recommend improvements and specify business requirements and priorities 
for solutions. System analysis is intended to provide the project team with a more thorough understanding of the problems and needs that trigger the project. At this stage an analysis of the needs and problems to be solved. In conducting the needs analysis process required source of information derived from order fulfillment. Then do the analysis of hardware and software that can run the application. In the process of collecting data is done by literature study, observation and interview.

Design, is a specification or construction of a technical and computerbased solution to the business requirements identified in the system analysis. During the design of the system, it will initially exploit alternative technical solutions. Once the alternative solution is approved, the system design phase develops the blueprints and technical specifications needed to implement the database, program, user interface and network required for the application.

Code or Programming, Designs that have been made then changed its shape into a form that can be understood by the machine, which is into the programming language through the process of coding. This stage is an implementation of the design stage that technically will be done by the programmer.

Implementation is the construction, installation, testing and delivery of the system into production (meaning daily operations). Implementation of the system implementations new information system and put it into operation, Implementation is a stage to realize the design of the design that has been done so that the results in accordance with the goals of system requirements. At this stage the rough framework that has been mapped at the design stage is implemented into the real design using the programming language.

Further testing is carried out. The testing stage is the stage to perform quality analysis of the software that has been developed so that the software is feasible to be used by the user.

Maintenance, software is needed, including in it is development, because the software is not always made that way. When run there may still be small errors that were not found before, or there are additional features that do not exist in the software. Development is needed when there is a change from an external company like when there is a change of operating system, or other device.

\section{RESULT AND DISCUSSION}

\section{On Going System}

Running a business for business owners, especially in SMB needs to consistently maintain a focus on operational capability. Most prominent owners in running the business carefully monitor various factors in their facilities such as internal processes, existing sales and even staff performance levels to ensure that all procedures are as effective as possible. Overall the company and productivity, they are not the only item that needs to get strategic attention when it becomes a crew of a manufacturing or distribution organization. When it wants to build industry credibility as a fully functional distribution center committed to complete customer satisfaction and demand, applying various forms of automatic automated order fulfillment is an absolute necessity.

Based on the development of Order Fulfillment Information System, a source of information is needed to direct a better development process. Therefore, business processes as information related to development have been obtained from businesses that need such information systems. The business process will be displayed in Figure 3. Business Process Computerized is created using Business Process Management Notation (BPMN) to various divisions that run business processes with computerized processes. 


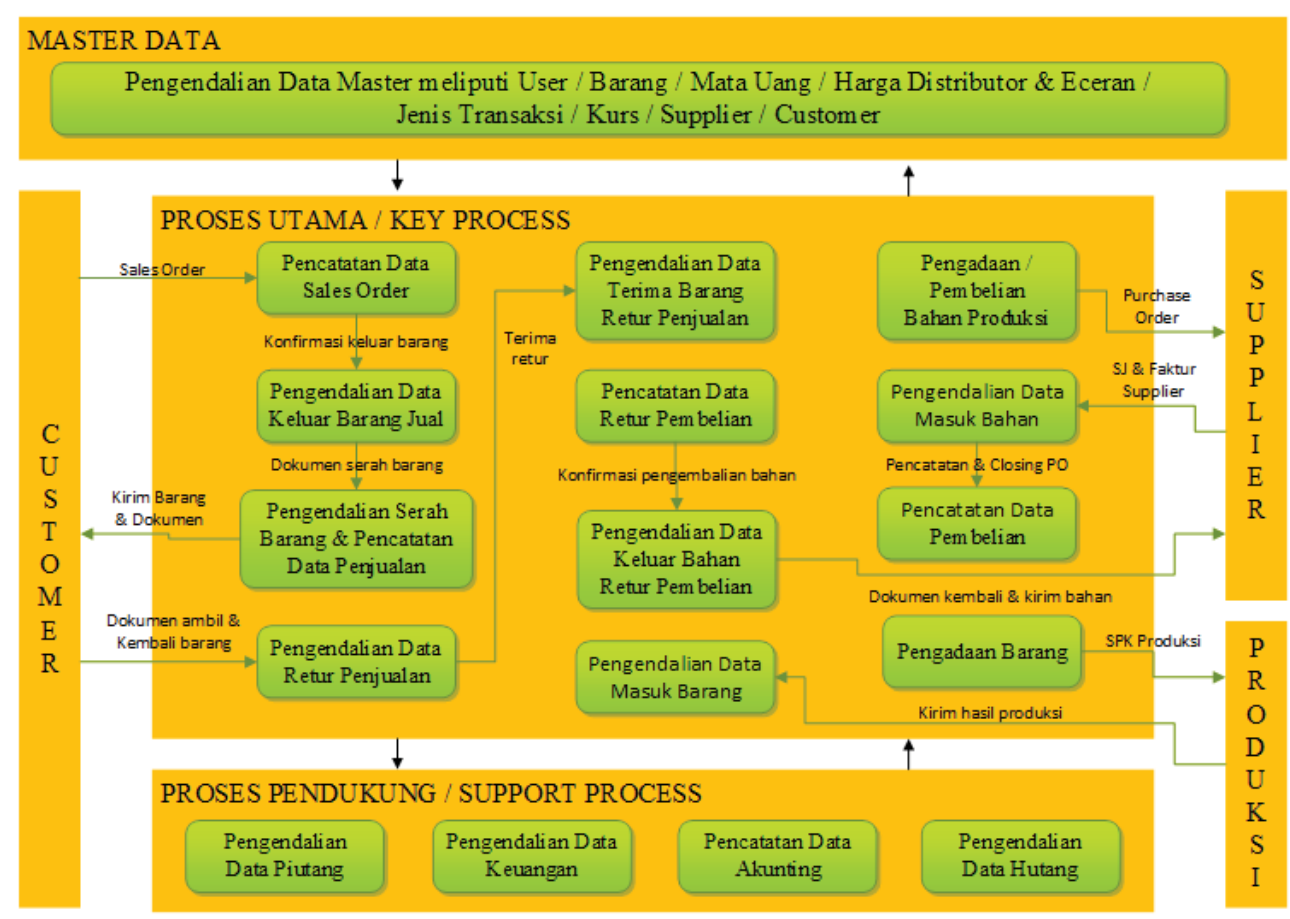

Figure 3. Business Process Computerized

Computerized Business Process has three parts, namely Master Data, Key Process, and Support Process. These three sections play an important role to the depiction of business processes that occur after the Order Fulfillment information system has been applied by the business. Master Data acts as a process where the users manage all the main data acting as a foundation to support all activities undertaken in the business process. Key Process acts as a process in which activities relate to the procurement of finished goods / finished goods production, sales recording (sales order, sales invoices, sales returns), purchase orders (purchases orders, purchase returns), and inventory control (handover goods, goods receipt, goods entered, materials entry). Support Process acts as a supporting process that plays a role in data control of accounts payable, accounts receivable, finance, and accounting is done to support all parts of the process described previously.

\section{Proposed System}

Based on the business processes described earlier, the analysis of the Order Fulfillment information system creation is made using Unified Modeling Language (UML). UML (Dennis et all, 2005) used is Use Case Diagram, and Activity Diagram made in general which is able to give an important picture or simple description to the whole analysis related to making information system. 


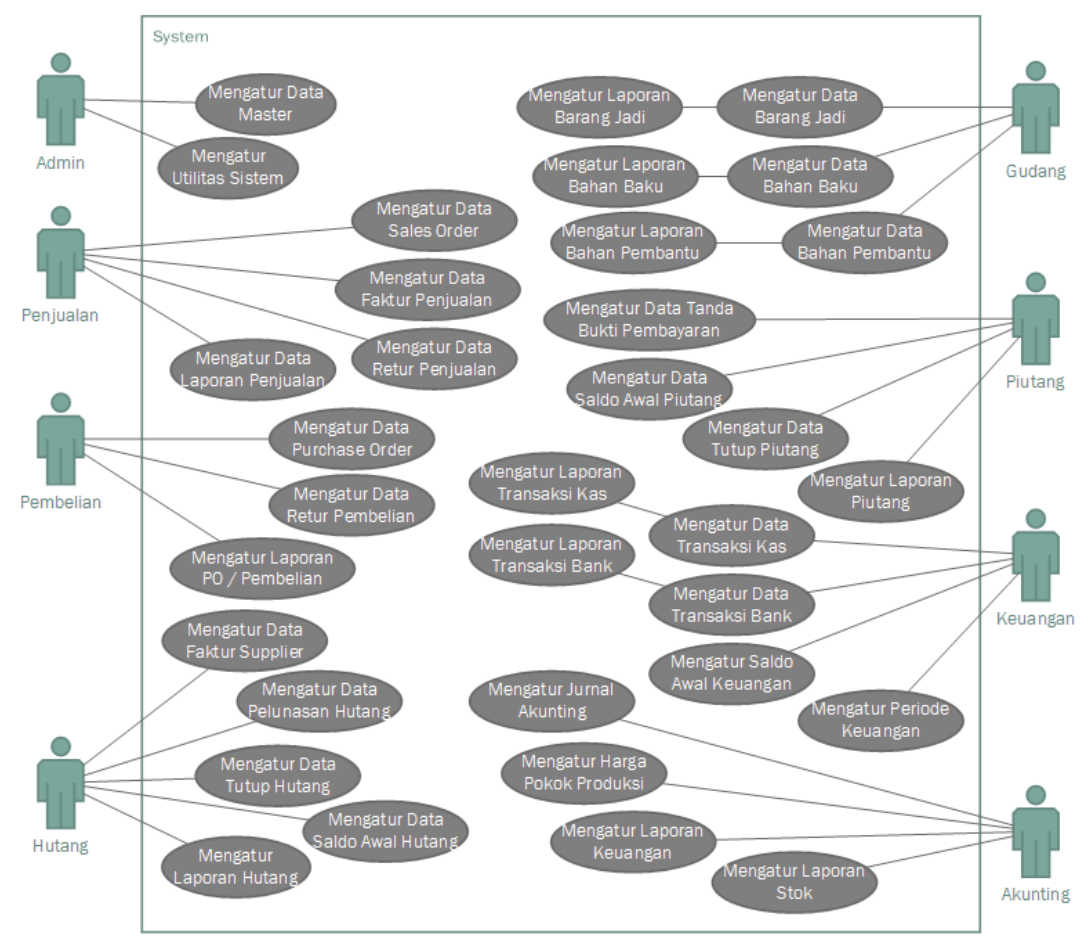

Figure 4. Use Case Diagram OFIS

Use Case Diagram in Figure 4. Use Case Diagram has various actors divided according to the division owned by the business. The division of shared actors is admin, sales, purchases, warehouses, accounts payable, accounts receivable, finance, and accounting. The division of actors is only done to provide a clearer picture of each scenario performed by the actor, and access rights can be flexibly arranged in the Order Fulfillment information system.

All scenarios in each process including data setting have a privilege for creating, altering and deleting data related to the scenario, while reporting is just a scenario in which the actor can display or produce reports according to the scenario.

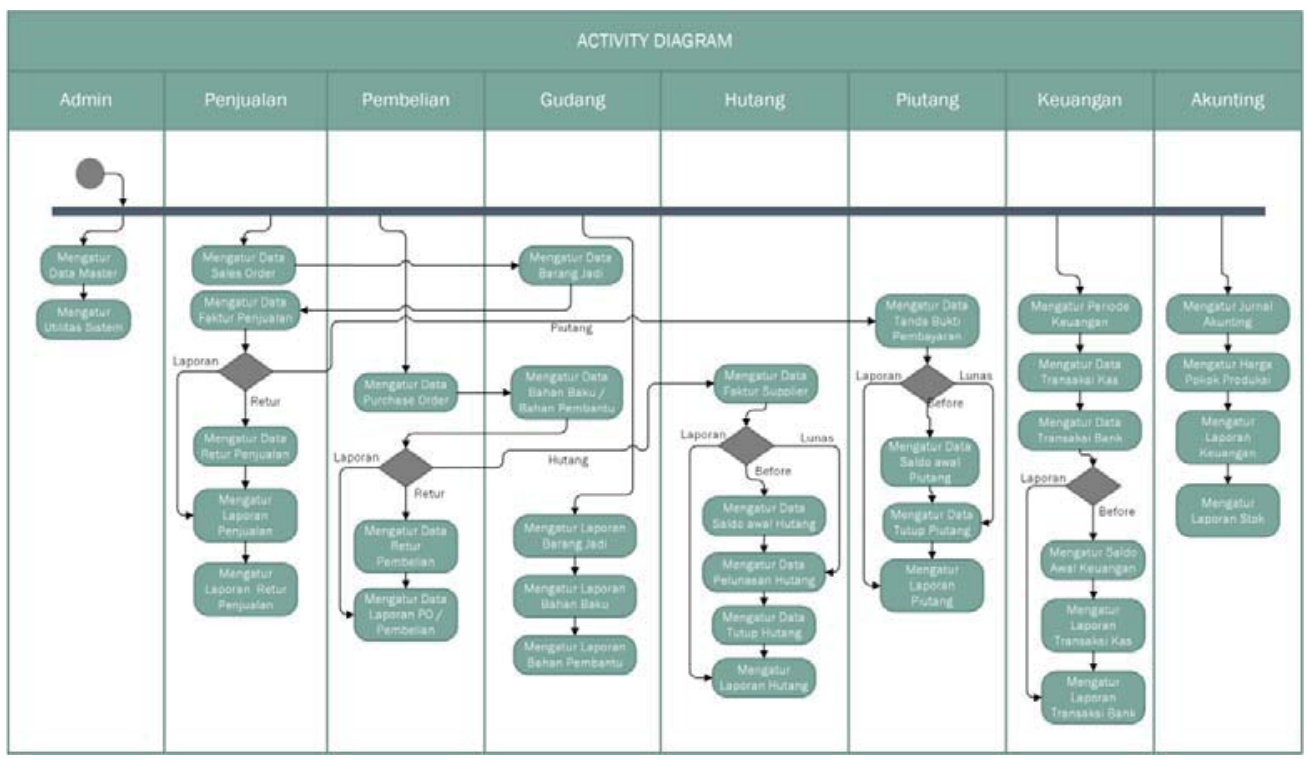


Figure 5. Activity Diagram

The Accounts Payable section has an action that can be initiated when the action on the Purchase section refers to the debt directly where the purchases made will become accounts payable and stored in the system. Not different from the process earlier, the Accounts Receivable section has an action too that can be initiated when the action on the Sales section refers to the Accounts receivable where the sale made has not received payment from the customer and will be recorded and stored as accounts receivable in the system. The Warehouse section may initiate action when a item related to the action in the Sales section is sold, and the receiving of the goods is related to the action on the Purchase section is initiated. Finally, the Finance section, accounting section, Admin section, Sales section, and Purchase section can start their action in accordance with the requests or needs required. The report activity on each section is placed at the end where the activity trigger is found, and can be done any time when the report is required without having to perform data settings of previous activities on a specific part.

Activity Diagram is created with some parts that are shared in the same case like the actor on the use case diagram, shown in figure 5. The sections are admin, sale, purchase, warehouse, accounts payable, accounts receivable, finance, and accounting. Activity diagrams that have been created illustrate how various actions on each part can be related to each other or as triggers to execute actions from that part.

\section{CONCLUSION}

Advantages possessed by Order fulfillment Information System for Small Medium Business are:

1. Fast data processing, the timeliness of the information received means that if the information received is too late Then this will reduce the value of the benefits of information itself. While one is wrong The benefit of information for the recipient is to make it a reference in the Decision maker. In business late retrieval. The decision will be able to eliminate the golden opportunity that should be achieved. No excessive if anyone says that a quick decision even a little. Less precise would be much better than the right decision but too late.

2. It has a high degree of information accuracy; accurate information is information that is full of certainty, as appropriate with the purpose of data processing, which is unbiased or does not contain errors. Information that will be used as a reference in decision making or The SMB policy-making must be accurate so that its impact can be felt of decision products or policies taken will be true or not produce wrong decision or policy. When the information in the system process is very Depending on the human ability (manual system) will be many weaknesses It certainly will reduce the accuracy of the information generated.

3. Efficiency of human resources, with the amount of data transactions many will need more personnel to do the job as data processor. There are journal recording officers, internal audits, Ledger officers, Officers Adjustment until the officer of the financial report maker. In the information system Computer-based accounting requires only one system operator which served as data entry transaction only, the rest of the data processing automatically.

4. Easy access to information, with the OFIS, the ease of information for management and staff can be implemented with the maximum, without having to wait for the decision of the business owner

\section{REFERENCES}

Andry, J. F., Agung, H., Erlyana, Y. (2016), Management Information System For 
Order Fulfillment: A Case Study, Proceeding of 9th International Seminar on Industrial Engineering and Management, Vol 9, ISSN: 1978-774X

Bassil, Y. (2012), A Simulation Model for The Waterfall Software Development Life Cycle, International Journal of Engineering \& Technology, vol. 2, no. 5 .

Croxton, K. L. (2002), The Order Fulfillment Process, The International Journal of Logistics Management, Vol 14, No 1, pp 1932.

Dennis, A., Wixom, B. H., Roth and Tegarden, D., (2005), Systems Analysis and Design with UML Version 2.0, An Object-Oriented Approach, Second Edition, John Wiley \& Sons, Inc.

Fawcett, S. E., Fawcett, A. M. (2014), "The Definitive Guide To Order Fulfillment And Customer Service, Principles And Strategies For Planning, Organizing, And Managing Fulfillment And Service Operations by Council of Supply Chain Management Professionals,' Published by Pearson Education, Inc.

Isac, C. (2014), E-Fulfillment - A New Challenge For Electronic Business Annals of the University of Petroşani Economics, Vol 14, No 1, pp 121128.

Murphy, J. V. (2004), Advanced Order Fulfillment Requires Warehouses With On Demand Capability, article at www.supplychainbrain.com access online January 11, 2017.

Rahmanto, N., Hartono, B., Tontowi, A. E. (2011), Analisis Manajemen Pemenuhan Pelanggan pada Industri Kecil Menengah Pembuatan Tas dan Bordir, Menggunakan Pemodelan System Dynamics (Studi Kasus pada
CV. Kurnia Jaya - Yogyakarta), Jurnal Manajemen dan Organisasi, Vol II, No 3 .

Pibernik, R. (2006), Managing stock-outs effectively with order fulfillment systems, Journal of Manufacturing Technology Management, 17(6), 721-736. 